The close liaison between the bronchitis registry, local general practitioners, chest clinic social workers, and health visitors made it possible to follow up all 233 registered patients with bronchitis from January 1963 to December 1970. Eleven (18\%) of the 60 deaths in this group were due to lung cancer, and all eleven deaths were in patients who did not have severe airways obstruction. This suggests that people with chronic bronchitis who do not have severe airways obstruction are more likely to die from lung cancer than those with bronchitis with severe airways obstruction.

The lack of deaths from lung cancer in registered bronchitic patients with severe airways obstruction was not due to failure to survive to lung cancer age because of earlier death from another cause: the mean age at death from all causes was 62 years, compared with 64 years for those who died from lung cancer, and this difference is not significant.

A study of mortality from bronchitis and lung cancer in England and Wales ${ }^{8}$ showed that death from bronchitis tended to occur later than death from lung cancer. Furthermore, more deaths from bronchitis and fewer deaths from lung cancer were found in coal-mining and textile-producing towns, and it was suggested that "bronchitis may have a protective effect on the lungs, and that the patient who has this chronic inflammatory and degenerative process at work may be at a relative advantage vis-à-vis his fellow with more normal lungs."

Our findings suggest that simple bronchitis and lung cancer often occur together and that obstructive bronchitis and lung cancer do not often occur together. This raises several questions. Is severe airways obstruction unfavourable to the development of lung cancer or is it associated with the same factor which protects against lung cancer ? Does the patient with severe airways obstruction give up smoking and so reduce his chances of developing lung cancer? Do repeated episodes of lung infection, which are commonly associated with obstructive bronchitis, enhance immunological defence against the malignant cell ? Does the severe airways obstruction of asthma also show a lack of association with lung cancer, as suggested in a report from Australia in which only one man among 13000 people with asthma observed over 12 years developed lung cancer ?12

Our findings pose but do not answer any of these questions. Further study of the lack of association between lung cancer and the severe airways obstruction of chronic bronchitis may provide a better understanding of both conditions.

We thank Dr. L. H. Capel for his constant encouragement and advice in the preparation of this paper; Dr. W. F. Wheeler for help in the follow-up of the bronchitis registry patients; Miss E. Hewison, chest clinic administrative officer, for her invaluable help; and Miss $M$. Rehahn for statistical help. We also thank the Chest and Heart Association for enabling us to establish the bronchitis registry.

\section{References}

${ }^{1}$ Royal College of Physicians of London, Smoking and Health Now. London, Pitman, 1971.

2 Case, R. A. M. and Lea, A. J., British fournal of Preventive and Social Medicine, 1955, 9, 62.

${ }^{3}$ Denoix, P. F., Schwartz, D. and Anguera, G., Bulletin de l'Association Francaise Pour l'Etude du Cancer, 1958, 45, 1 .

${ }^{4}$ Campbell, A. H. and Lee, E. J., British Fournal of Diseases of the Chest, 1963, 57, 113.

5 Rimington, J., British Medical fournal, 1968, 1, 732.

${ }^{6}$ Rimington, J., British Medical Fournal, 1971, 2, 373.

${ }^{7}$ Ashley, D. J. B. and Davies, H. D., British fournal of Preventive and Social Medicine, 1966, 20, 148.

${ }^{8}$ Ashley, D. J. B., British fournal of Cancer, 1967, 21, 243.

${ }^{\circ}$ Caplin, M., Capel, L. H., and Wheeler, W. F., British fournal of Diseases of the Chest, 1964, 58, 97.

${ }^{10}$ Medical Research Council Committee on the Aetiology of Chronic Bronchitis, British Medical founral, 1960, 2, 1665.

11 Legge, J. S., and Palmer, K. N. V., Thorax, 1973, 28, 588.

12 Ford, R. M., British Medical fournal, 1971, 3, 372.

\title{
Hyperparathyroidism after Renal Transplantation
}

\author{
MICHAEL KLEEREKOPER, LLOYD S. IBELS, JOAN P. INGHAM, STANLEY W. MCCARTHY, \\ JOHN F. MAHONY, JOHN H. STEWART, SOLOMON POSEN
}

British Medical fournal, 1975, 3, 680-682

\section{Summary}

Renal transplantation reduced circulating parathyroid hormone in recipients of renal allografts. Nevertheless, biochemical and histological evidence of mild hyperparathyroidism persisted up to eight years after renal transplantation despite good graft function.

Departments of Medicine, Morbid Anatomy, and Medical Research, Sydney Hospital, Sydney, New South Wales, Australia

MICHAEL KLEEREKOPER, M.B., B.S., Research Fellow, Department of Medicine

LLOYD S. IBELS, M.B., M.R.A.C.P., Registrar, Immunology and Renal Unit

JOAN P. INGHAM, M.B., F.R.A.C.P., Research Fellow, Department of Medicine

STANLEY W. McCARTHY, M.B., F.R.C.P.A., Deputy Director of Morbid Anatomy

JOHN F. MAHONY, M.B., F.R.A.C.P., Physician, Immunology and Renal Unit

JOHN H. STEWART, M.B., F.R.A.C.P., Renal Physician

SOLOMON POSEN, M.D., F.R.C.P., Associate Professor of Medicine

\section{Introduction}

The effects of renal transplantation on secondary hyperparathyroidism have been well documented. ${ }^{1-7}$ In most patients the radiological and biochemical changes of hyperparathyroidism regress after transplantation so that parathyroidectomy is rarely needed, ${ }^{6}$ but there are conflicting reports ${ }^{5-7}$ on the rate and extent of this regression.

Hence we investigated parathyroid function in 71 recipients of cadaveric renal allografts with biochemical, radioimmunological, and histological techniques. This is the first paper in which skeletal histology has been systematically studied in renal allograft recipients with good graft function.

\section{Patients and Methods}

Two groups of renal allograft recipients were investigated. The first group consisted of 11 patients (four men and seven women) who were studied before transplantation and during the subsequent three months. The second group consisted of 60 patients $(30$ men and 30 women) who had received renal transplants from six and a half to 95 months (median 46 months) before this study, after haemodialysis ranging from a few days to two years (mean 7.2 months). In 40 of 
these patients (20 men and 20 women) the serum creatinine was $115 \mu \mathrm{mol} / 1 \mathrm{l}(1.3 \mathrm{mg} / 100 \mathrm{ml})$ or less, while in the remaining 20 it ranged from 124 to $265 \mu \mathrm{mol} / \mathrm{l}(1.4$ to $3.0 \mathrm{mg} / 100 \mathrm{ml})$. All patients were receiving immunosuppressive treatment: prednisone 7.5-20.0 (mean 12.0) mg per day and azathioprine 100-275 (mean 189) mg per day. No patient was receiving aluminium hydroxide and only four hypercalcaemic patients were receiving inorganic phosphate.

All blood samples were collected in the morning after an overnight fast and all the biochemical values, including immunoreactive parathyroid hormone (PTH), were measured on one serum specimen. Serum calcium, inorganic phosphate, creatinine, and alkaline phosphatase were measured by standard techniques. ${ }^{8-11}$ The methods used for the radioimmunoassay of serum $\mathrm{PTH}$, iliac crest trephine biopsy, and semi-quantitative histological assessment of hyperparathyroidism have been described. ${ }^{12}{ }^{13}$ The PTH radioimmunoassay ${ }^{12}$ measures intact bovine $\mathrm{PTH}$ as well as $\mathrm{N}$-terminal bovine and human fragments. Measurable circulating PTH in patients with hyperparathyoidism disappears with a biological half-life of about 10 minutes when this assay is used.

All investigations, except the iliac crest biopsy, were also performed on two groups of people who had not received transplants-40 normal volunteers matched for age and sex with those allograft recipients whose serum creatinine was $115 \mu \mathrm{mol} / \mathrm{l}$ or less and 16 patients with mild chronic renal failure matched for age, sex, and serum creatinine with those allograft recipients whose serum creatinine was 124 to $265 \mu \mathrm{mol} / \mathrm{l}$.

Statistical calculations were performed according to standard methods. ${ }^{14}$

\section{Results}

The fall in serum PTH concentration and serum creatinine during the first three months after transplantation is shown in the fig. Immunoreactive PTH was raised in all patients before transplantation while a normal level was present in only one patient three months after operation. Serum PTH and serum creatinine fell concurrently during the study, the greatest fall occurring during the first week. A statistically insignificant rise in serum PTH was seen during the second week after operation in six out of 11 patients.

Hypercalcaemia occurred for the first time in the period immediately after transplantation in one of these 11 patients. It persisted from before the operation in one other patient. Renal transplantation was nevertheless followed by a fall in serum PTH in both cases.

Biochemical data on 40 long-term allograft recipients with "normal" renal function are given in table I together with data on the age- and sex-matched control group. The patients had a higher mean serum calcium and a lower mean serum inorganic phosphate than the controls despite their mean serum creatinine being higher than that of the controls. Serum alkaline phosphatase activities were raised above $100 \mathrm{IU} / 1$ in three of these patients. In each case heat inactivation studies $^{15}$ showed that the phosphatase did not arise from bone.

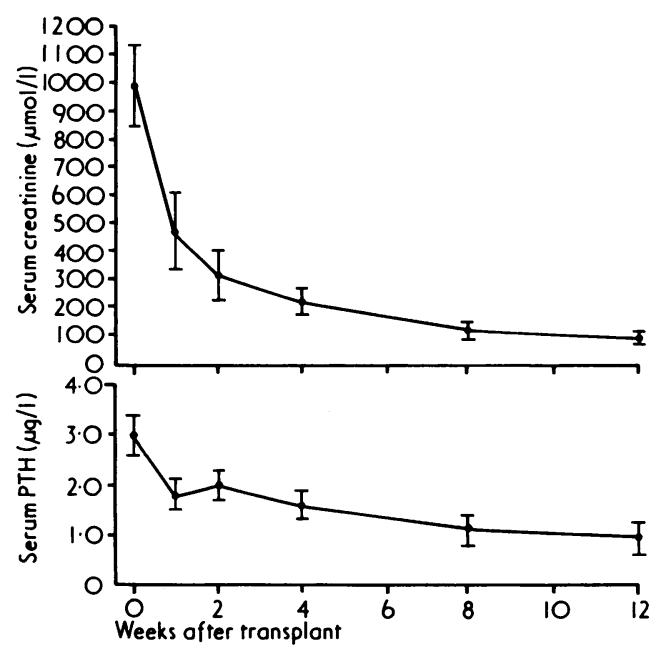

Mean ( \pm S.E. of mean) serum immunoreactive PTH and serum creatinine concentrations in 11 patients during first three months after renal transplantation.

Conversion: SI to Traditional Units-Creatinine: $1 \mu \mathrm{mol} / 1 \approx 0.0113$ $\mathrm{mg} / 100 \mathrm{ml}$.
TABLE I-Serum Biochemical Values in Recipients of Renal Allografts with Serum Creatinine $<115 \mu \mathrm{mol} / \mathrm{l}$

\begin{tabular}{|c|c|c|c|}
\hline & $\begin{array}{l}\text { Allograft } \\
\text { Recipients } \\
(\mathrm{N}=40)\end{array}$ & $\begin{array}{l}\text { Normal } \\
\text { Subjects } \\
(\mathbf{N}=40)\end{array}$ & $\mathbf{P}$ \\
\hline $\begin{array}{l}\text { Creatinine }(\mu \mathrm{mol} / \mathrm{l}) \\
\text { Calcium }(\mathrm{mmol} / \mathrm{l}) \\
\text { Inorganic phosphate }(\mathrm{mmol} / \mathrm{l}) \\
\text { PTH }(\mu \mathrm{g} / \mathrm{l})\end{array}$ & $\begin{array}{l}88 \cdot 4 \pm 17 \cdot 7 \\
2 \cdot 55 \pm 0 \cdot 10 \\
0 \cdot 94 \pm 0 \cdot 16 \\
0 \cdot 4 \pm 0 \cdot 6\end{array}$ & $\begin{array}{l}79 \cdot 6 \pm 8 \cdot 8 \\
2 \cdot 48 \pm 0 \cdot 03 \\
1 \cdot 16 \pm 0 \cdot 13 \\
0.2 \pm 0.2\end{array}$ & $\begin{array}{l}<0.05 \\
<0.005 \\
<0.001 \\
<0.05\end{array}$ \\
\hline
\end{tabular}

Conversion: SI to Traditional Units

Creatinine: $1 \mu \mathrm{mol} / 1 \approx 0.0113 \mathrm{mg} / 100 \mathrm{ml}$

Calcium: $1 \mathrm{mmol} / 1 \approx 4 \mathrm{mg} / 100 \mathrm{ml}$.

Phosphate: $1 \mathrm{mmol} / \approx 3.1 \mathrm{mg} / 100 \mathrm{ml}$.

TABLE II- Serum Biochemical Values in Recipients of Renal Allografts with Impaired Graft Function

\begin{tabular}{|c|c|c|c|}
\hline & $\begin{array}{l}\text { Allograft } \\
\text { Recipients } \\
(\mathrm{N}=20)\end{array}$ & $\begin{array}{c}\text { Chronic Renal } \\
\text { Failure } \\
(\mathbf{N}=16)\end{array}$ & $\mathbf{P}$ \\
\hline $\begin{array}{l}\text { Creatinine }(\mu \mathrm{mol} / \mathrm{l}) \\
\text { Calcium }(\mathrm{mmol} / \mathrm{l}) \\
\text { Inorganic phosphate (mmol/l) } \\
\text { PTH }(\mu \mathrm{g} / \mathrm{l})\end{array}$ & $\begin{array}{c}159 \cdot 1 \pm 35.4 \\
2.58 \pm 0.13 \\
1.07 \pm 0.26 \\
0.5 \pm 0.5\end{array}$ & $\begin{array}{c}168 \cdot 0 \pm 35 \cdot 4 \\
2 \cdot 40 \pm 0 \cdot 13 \\
1 \cdot 20 \pm 0 \cdot 19 \\
0 \cdot 4 \pm 0 \cdot 4\end{array}$ & $\begin{array}{l}<0.001 \\
\text { NS } \\
\text { NS }\end{array}$ \\
\hline
\end{tabular}

Four patients in the group had hypercalcaemia. A further five patients with long-term, stable allografts and normal renal function were hypophosphataemic (serum inorganic phosphate $<0.775 \mathrm{mmol} / \mathrm{l}$ $(<2.4 \mathrm{mg} / 100 \mathrm{ml})$. The highest serum $\mathrm{PTH}$ in this group of patients was $3.4 \mu \mathrm{g} / 1$

Table II lists the biochemical data in 20 allograft recipients with mildly impaired graft function and 16 controls with mild chronic renal failure. The mean serum calcium in the transplanted group was significantly higher than that in the control group $(P<0.001)$, though the mean serum inorganic phosphate and PTH values were not significantly different in the two groups of patients. All but one of the allograft recipients had detectable levels of PTH, while eight patients had raised serum PTH concentrations.

Iliac crest trephine biopsies were performed in 39 of the 60 patients with long-term renal allograft survival. Skeletal histological findings were normal in seven patients while minimal changes of hyperparathyroidism (bone scole of 1 on a scale of $0-3$ ) were seen in 27 patients. Five patients had "moderate" changes (bone score of 2). The correlation between serum PTH and the skeletal histological findings was significant at the $5 \%$ level.

Significant osteomalacia ${ }^{13}$ (osteoid index $=3.8 \%$ ) was present in one patient. Four further patients had osteoid indexes of $1-2 \%$. The remaining patients showed no increase in uncalcified osteoid.

No relation could be established between the duration of haemodialysis and any of the biochemical or histological values.

\section{Discussion}

Some $70 \%$ of patients with end-stage renal failure have histological hyperparathyroidism. ${ }^{16-17}$ There is evidence $^{18}$ that the skeletal lesions are exacerbated by haemodialysis, especially if the dialysate calcium concentration is inadequate. ${ }^{1-20}$ The prevalence and persistence of hyperparathyrodism among recipients of renal allografts have been controversial topics. Early workers ${ }^{7}$ stated that serum PTH returned to normal within four to six months of operation provided the creatinine clearance was greater than $60 \mathrm{ml} / \mathrm{min}$. Pletka et al. ${ }^{21}$ and David et al. ${ }^{6}$ however, reported raised PTH levels and hypercalcaemia in allograft recipients with normal renal function up to four years after operation. Casaretto et al. ${ }^{22}$ found high immunoreactive $\mathrm{PTH}$ concentrations in 31 allograft recipients with a mean serum creatinine of $141.1 \mu \mathrm{mol} / 1(1.6 \mathrm{mg} / 100 \mathrm{ml})$ but reported no histological data. Our results show that patients who have had a renal transplant may have biochemical and histological hyperparathyroidism in spite of good graft function eight years after surgery.

The mechanism of this persistent abnormality is uncertain. Hyperparathyroidism in allograft recipients does not merely 
reflect reduced renal function, 5 and long-term steroid and immunosuppressive drug administration have no influence on serum PTH. ${ }^{23}$ It is therefore likely that the histological and biochemical changes in these patients are due to the slow rate of parathyroid gland involution.

We have shown a positive correlation between serum PTH concentrations, parathyroid gland weights, and skeletal histology in primary hyperparathyroidism, ${ }^{12}$ and Ellis and Peart ${ }^{24}$ have shown a similar correlation between gland weights and skeletal histology in patients with renal failure. It is difficult to obtain comparable data on parathyroid gland weights after renal transplantation, though we have some necropsy data ${ }^{25}$ suggesting that about half the allograft recipients who die with a functioning graft in situ 12 months or more after transplantation have macroscopically enlarged parathyroid glands.

The reason why parathyroid enlargement and hypersecretion persist in some patients but not in others is unknown. The abnormalities in our patients were mild and at the time of writing no allograft recipient had undergone parathyroidectomy.

This work was supported by the National Health and Medical Research Council of Australia, the New South Wales State Cancer Council, and the University of Sydney Cancer Research Fund. Many of the biochemical determinations were performed in the laboratory of Dr. F. C. Neale. Susan Vedelago, Margaret Wilkinson, Ruth Monk, Deborah Steele, and Deborah Reynolds gave skilful technical and secretarial help.

Requests for reprints should be addressed to Professor S. Posen, Department of Medicine, Sydney Hospital, Sydney, N.S.W. 2000, Australia.

\section{References}

1 Alfrey, A. C., et al., New England Fournal of Medicine, 1968, 279, 1349.

2 Bricker, N. S., et al., Archives of Internal Medicine, 1969, 123, 543.

3 Johnson, J. W., et al., Metabolism, 1971, 20, 487.

4 Johnson, W. J., Goldsmith, R. S., and Arnaud, C. D., Medical Clinics of North America, 1972, 56, 961.

5 Case Records of the Massachusetts General Hospital, New England fournal of Medicine, 1974, 290, 793.

6 David, D. S., et al., New England fournal of Medicine, 1973, 289, 398.

7 Johnson, J. W., et al., fournal of the American Medical Association, 1971, 215,478 .

${ }^{8}$ Fingerhut, B., Poock, A., and Miller, H. Clinical Chemistry, 1969, 15, 870.

9 Young, D. S., fournal of Clinical Pathology, 1966, 19, 397.

10 Morgenstern, S., et al., Clinical Chemistry, 1965, 11, 876.

11 Chasson, A. L., Grady, H. J., and Stanley, M. A., American fournal of Clinical Pathology, 1961, 35, 83.

12 Kleerekoper, M., et al., Clinical Chemistry, 1974, 20, 369.

13 Garrick, R., Doman, P., and Posen, S., Clinical Science, 1972, 43, 789.

14 Snedecor, G. W., and Cochran, W. G., Statistical Methods, 6th edn. Ames, Iowa, Iowa State University Press, 1967.

15 Posen, S., Neale, F. C., and Clubb, J. S., Annals of Internal Medicine, $1965,62,1234$.

16 Kaye, M., et al., in Proceedings of the IVth International Congress of Nephrology, vol. 3, p. 151. Basel, Karger, 1970.

17 Ingham, J. P., Stewart, J. H., and Posen, S., British Medical fournal, $1973,2,745$.

18 Ingham, J. P., et al., unpublished observations.

19 Johnson, J. W., et al., Metabolism, 1972, 21, 18.

20 Fournier, A. E., et al., Fournal of Clinical Investigation, 1971, 50, 599.

21 Pletka, P., et al., in Abstracts of Papers presented at the Vth International Congress of Nephrology, Mexico, 1972.

2.2 Casaretto, A., et al., Lancet, 1974, 1, 481.

${ }^{23}$ Kleerekoper, M., unpublished observations.

$2+$ Ellis, H. A., and Peart, K. M., Fournal of Clinical Pathology, 1973, 26, 83.

${ }^{25} \mathrm{McC}$ arthy, S. W., unpublished observations.

\begin{abstract}
Summary
Acetylator capacity was determined in two groups of patients who had received procainamide for more than three months. In seven patients antinuclear antibodies (A.N.A.) were detected during treatment, and these changes disappeared (in six patients) or were less pronounced (one patient) after withdrawal of the drug. These patients tended to have faster acetylation rates, and five were phenotypically "rapid" acetylators. Five patients who did not develop A.N.A. during treatment had less rapid $(P<0.05)$ rates of acetylation, and four were "slow" acetylators. We suggest that the immunological changes which may occur during procainamide treatment may be associated with the acetylated metabolite of procainamide rather than the parent compound and that it might be possible to identify patients at risk.

\section{Introduction}

Acetylation is the metabolic pathway through which drugs such as hydrallazine, ${ }^{1}$ isoniazid, ${ }^{2}$ dapsone, ${ }^{3}$ phenelzine, ${ }^{4}$ and many sulphonamides ${ }^{5}$ are inactivated. Acetylation rates are

University Department of Pharmacological Sciences (Clinical

Pharmacology), Newcastle upon Tyne NE1 7RU

D. M. DAVIES, F.R.C.P., Senior Lecturer

M. A. BEEDIE, M.B., M.R.C.P., Honorary Research Associate

M. D. RAWLINS, M.D., M.R.C.P., Professor
\end{abstract}

bimodally distributed within populations because of a genetic polymorphism. ${ }^{6}$ Adverse effects from hydrallazine, ${ }^{7}$ isoniazid, ${ }^{*}$ dapsone, and phenelzine ${ }^{4}$ are commoner in patients who are phenotypically "slow" acetylators, in whom the slower rates of elimination are presumed to lead to a persistence of the drug in the body. In particular, the development of circulating antinuclear antibodies (A.N.A.) during treatment with hydrallazine is more common in such patients, and clinical evidence of hydrallazine-associated systemic lupus erythematosus (S.L.E.) is apparently confined to those with the "slow" acetylator phenotype.

Procainamide also undergoes extensive acetylation in man, ${ }^{9}$ and this may be under polymorphic control. ${ }^{10}$ Prolonged treatment with procainamide is associated in some patients ${ }^{11}$ with the development of circulating A.N.A. which may be accompanied by a syndrome clinically resembling S.L.E. ${ }^{11} 1:$ We have tried to establish whether these changes are related to a person's capacity to acetylate drugs.

\section{Patients and Methods}

Twelve patients were investigated (see table). All had received procainamide for over three months, and none were given it during the determination of their acetylator capacity. In the seven patients in group 1 (see table) antinuclear factor (A.N.F.) was detected during procainamide treatment by means of nuclear histofluorescence, and blood from five of them also showed the L.E. cell phenomenon; L.E. cells were not found in case 6 and were not sought in case 2 . Procainamide treatment was withdrawn from all seven patients, and six of them showed complete disappearance of A.N.F. and L.E. cells. Case 3, however, remained weakly positive for A.N.F. for two years. The five patients in group 2 (see table) received long-term treatment 